\title{
Entrepreneurship Education in Health Care Education
}

\author{
L. Salminen, ${ }^{1}$ E. Lindberg, ${ }^{1}$ M.-L. Gustafsson, ${ }^{1}$ J. Heinonen, ${ }^{2}$ and H. Leino-Kilpi ${ }^{3}$ \\ ${ }^{1}$ Department of Nursing Science, University of Turku, Lemminkäisenkatu 1, 20014 Turku, Finland \\ ${ }^{2}$ Turku School of Economics, TSE Entre, University of Turku, Finland \\ ${ }^{3}$ Department of Nursing Science, Hospital District of South-West Finland, University of Turku, Turku, Finland
}

Correspondence should be addressed to L. Salminen; leena.kaarina.salminen@utu.fi

Received 28 May 2014; Revised 13 October 2014; Accepted 20 October 2014; Published 11 November 2014

Academic Editor: Yi-Shun Wang

Copyright (C) 2014 L. Salminen et al. This is an open access article distributed under the Creative Commons Attribution License, which permits unrestricted use, distribution, and reproduction in any medium, provided the original work is properly cited.

\begin{abstract}
This study describes the content of entrepreneurship education in health care education and the kinds of teaching methods that are used when teaching about entrepreneurship. Health care entrepreneurship has increased in many countries in recent decades and there is evidence that entrepreneurs have also a role in public health care. Therefore the health care professionals need to be educated to have the entrepreneurial skills. Education in the field of health care is still based on traditional forms of teaching and does not give enough attention to the issue of becoming an entrepreneur. The data was collected from teachers $(n=111)$ via e-mail from six Finnish polytechnics. The data were analysed statistically and the open-ended questions were analysed via content analysis. Approximately $23 \%$ of the teachers had taught about entrepreneurship. The most popular teaching methods were company visits and cases, lecturing, and project work. The courses dealt with establishing a company, entrepreneurship in general, and marketing. Nearly all of the teachers had cooperated with the entrepreneurs or with the companies in question. Approximately $33 \%$ of the teachers took entrepreneurship into consideration often in other courses related to entrepreneurship.
\end{abstract}

\section{Introduction}

Entrepreneurship in the health care sector is not a new phenomenon. Already before World War II, many nurses worked as entrepreneurs. After the war, nurses began to work in public services in many countries due to social and economic changes. Approximately $1 \%$ of all nurses work as entrepreneurs [1]. A nurse is defined as an entrepreneur if he or she offers different nursing services in private-sector markets: care, education, research, and administrative work [1-3]. Social, political, and economic factors such as an economic crisis, the dissatisfaction of nurses with their work, and changes in the health needs of the population and consumers have caused more nurses to become entrepreneurs during the last decades $[1,2,4]$. The development, scope of practise, and regulation of nurse entrepreneurs will also depend on economic infrastructure and policies implemented at the national, regional, and local levels $[1,5]$. The notion of entrepreneurship is not relevant for clinical nurses only; it is relevant for any nurses who are in managerial positions and need to understand changes in the organizational process.

During times of economic uncertainty, knowledge about entrepreneurship and entrepreneurial skills can be exploited when health care staff needs to figure out how to do more with fewer resources [4]. Some studies indicate that a lack of competence in entrepreneurship is a major barrier for nurses who want to become entrepreneurs [6-8]. Nurse entrepreneurs claim that when their education is based on the traditional forms of nursing, it does not provide them with enough knowledge about entrepreneurship or establishing and running a company [7-9]. Therefore, a critical discussion about the role of education in enhancing entrepreneurship among nurses is needed. This study addresses the issue by describing entrepreneurship education in six different Finnish polytechnics. Based on a survey conducted among teachers in the health care field, we focus on the scope and nature of entrepreneurship education as well as on the methods that teachers use when addressing the issue of entrepreneurship.

\section{Background}

Entrepreneurship is becoming increasingly important within the health care sector as societal changes give space for new entrepreneurs in the field $[1,4,10]$. However, quite 
a little research has been done on entrepreneurship in the health care sector and particularly on enterprise education in nursing education. Previous studies have identified a number of obstacles that may hinder nurses from becoming entrepreneurs, such as a lack of business competence and skills, economic obstacles (e.g., business cycles), and a lack of support from their colleagues and society in general [68]. In addition, entrepreneurship in the health care sector is also dependent on the politics related to public health care services, for example, social enterprises $[5,11]$. Some studies indicate that a lack of competence in entrepreneurship is a major barrier for nurses who want to become entrepreneurs $[1,6-8]$. Nurse entrepreneurs claim that when their education is based on the traditional forms of nursing, it does not provide them with enough knowledge about entrepreneurship or establishing and running a company [7-9]. Therefore, a critical discussion about the role of education in enhancing entrepreneurship among nurses is needed [1].

This study addresses the issue by describing entrepreneurship education in Finnish polytechnics. The Ministry of Culture and Education (2009) [12] in Finland requires entrepreneurship education in all levels of education. It means, at the secondary level and in higher education, the knowledge and skills are developed further, including competencies relating to entrepreneurship. An entrepreneurial culture and procedures are best realized in cooperation with the operational environment according to the objectives set for entrepreneurship education at each level of education (also European Commission 2008 [13]).

In entrepreneurship research there is no single theory for entrepreneurship. Even the concept of entrepreneurship is somewhat ambiguous; the research in the field focuses on several different themes, such as entrepreneurship theory, types of entrepreneurs, the entrepreneurial process, organizational forms, the external environment, and outcomes [14]. In this study we exploit a pragmatic conceptualization of entrepreneurship instead of a theoretical one. The European Commission has adopted a rather broad definition of entrepreneurship:

\begin{abstract}
Entrepreneurship refers to an individual's ability to turn ideas into action. It includes creativity, innovation and risk taking, as well as the ability to plan and manage projects in order to achieve objectives. This supports everyone in day-to-day life at home and in society, makes employees more aware of the context of their work and better able to seize opportunities, and provides a foundation for entrepreneurs establishing a social or commercial activity. (European Commission, 2006, page 4 [15]).
\end{abstract}

The definition of entrepreneurship encompasses the central aspects of entrepreneurship in a theoretical sense, that is, enterprising individuals exploring, identifying and exploiting opportunities $[16,17]$, creatively breaking patterns, taking and managing risk, and organizing and coordinating resources $[18,19]$. In addition, it acknowledges that entrepreneurship and opportunity exploitation do not necessarily imply the creation of new firms but can also take place within existing organizations (see Shane and Venkataraman, 2000 [16]). This brings us to the concept of intrapreneurship and corporate entrepreneurship [20], by which we refer to the practice of developing new ventures and strategic renewal within an existing organisation in order to exploit new opportunities and generate economic value [21]. Intrapreneurship is defined here as entrepreneurship within an existing organisation regardless of size. In health care it means that salaried nurse develops, promotes, and delivers an innovative health care or nursing practice [1]. The definition of entrepreneurship, thus, covers all types of entrepreneurial movements, from starting up and running a company to behaving in an entrepreneurial manner in any sphere of one's life.

The different aims and objectives of entrepreneurship education include increasing the knowledge base of participants (learning to understand entrepreneurship), improving their entrepreneurial abilities and behaviour in life (learning how to become entrepreneurial in their outlook), and providing them with the relevant set of skills and competences for establishing a new start-up company or managing an existing firm (learning to become an entrepreneur) [22, 23]. The objectives of entrepreneurship education overlap at least to some extent as an increased understanding on the phenomenon of entrepreneurship is likely to influence participant's start-up skills or other entrepreneurial competences, for example. However, the different objectives of a particular programme have implications in terms of how entrepreneurship is taught $[22,24]$. Through entrepreneurship education, the students gain information about entrepreneurship and its role in society. Learning to become an entrepreneur involves teaching the students how to take responsibility for their own learning, career, and life [22, 25, 26]. Related skills include, for example, taking responsibility risks and taking initiative as well as showing innovativeness [25, 27]. Learning to become an entrepreneur involves learning about the issues related to business start-ups and the running of a company [26].

The content of entrepreneurship education depends on the objectives of the education in question, which also has to do with the target group of the entrepreneurship programme [28]. Berry et al. (2014) [29] suggest that entrepreneurship programs should focus on functional knowledge and an opportunity exists to include courses that address innovation, design, intellectual property, and social media. In entrepreneurship education, the teaching and learning methods in particular are of great importance because teaching about entrepreneurship involves both arts (e.g., creative and innovative thinking) and sciences (e.g., business competence and management skills) [30, 31]. In addition, the teaching methods and pedagogy should be in line with the objectives set for the programme $[32,33]$. However, based on previous research, traditional teaching methods such as lecturing, reading the relevant literature, and writing essays were the most popular teaching methods in enterprise education [26, 34].

It is useful to teach the concepts of entrepreneurship using traditional methods; however, it is difficult for students to gain a deeper understanding of enterprising when traditional methods are used [20, 22]. Therefore, learning through action and via target-oriented and social learning methods 
is emphasized in entrepreneurship education [8]. As the objectives often include teaching students to run and manage (entrepreneurial) organizations as a whole, it is usually necessary that entrepreneurship programmes establish a close relationship between working life, practice, and business. This gives the programmes a practical "flavour" and offers the students an opportunity to familiarize themselves with different types of companies and organizations in the health care sector.

The purpose of the study was to describe the content of entrepreneurship education in the health care sector and the kinds of teaching methods that are used in teaching entrepreneurship.

The following research questions were set.

(1) What are the objectives and the content of entrepreneurship education in health care education?

(2) What kinds of teaching methods are used in teaching entrepreneurship in health care education?

(3) How do teachers cooperate with entrepreneurs?

\section{Materials and Methods}

3.1. Data Collection. The data was collected via an e-mail in which the link to the questionnaire was from teachers working in the health care field in randomly chosen six Finnish polytechnics in year 2009. In Finland there were at that moment 23 polytechnics where the health care education programs were located. The questionnaire was sent to 474 all health care teachers in chosen polytechnics; their e-mail addresses were obtained from the polytechnics participating in the study. After sending one reminder 111 health care teachers responded to the questionnaire yielding a response rate of $23 \%$.

3.2. The Questionnaire. The data was collected using a questionnaire developed for this study based on the existing literature. The questionnaire included background factors and questions about entrepreneurship teaching and cooperation between teachers and entrepreneurs. The background factors included gender, title, training programme, earlier experience as an employee in an enterprise or acting as an entrepreneur, whether any relatives work as entrepreneurs, teaching about entrepreneurship, and earlier entrepreneurship education. The teachers were asked whether they teach about entrepreneurship on their own or in some other degree programme.

The content and objectives of entrepreneurship courses were asked via an open-ended question to talk about the most central contents of the course. Concerning the teaching methods teachers were asked to choose from a list of alternatives the types of teaching methods that they have used when teaching about entrepreneurship. The teachers were also asked using a four-point Likert scale question (never, seldom, quite often, and often) how often they take entrepreneurship into consideration in their other teaching activities and how often they cooperate with entrepreneurs.
3.3. Data Analysis. Data analyses were performed using the statistical program SPSS 16.0. Descriptive statistics and frequency tables were used to characterize the variables. An Independent Samples $t$-Test was used to compare the mean scores. For multigroup background variables, the groups were compared using the One-Way ANOVA technique. The dependence between background variables and individual items was analysed using Pearson's chi-squared tests or Fisher's exact tests. Observed significance levels of $P<$ 0.05 were considered statistically significant and only those significance levels are reported. Open-ended questions were analysed using content analysis [30].

3.4. Ethical Considerations. This study was not ethically problematic. The data were only collected from the randomly chosen polytechnics that had given us permission to do the study. The polytechnics sent the teachers' e-mail lists or lists of names to us. The Webropol programme provided a link to the questionnaire via e-mail. A cover letter explaining the study was provided with the link. The cover letter mentioned that the study was entirely voluntary and anonymous. The Webropol programme does not disseminate the names of respondents. The returned questionnaire was regarded as informed consent to participate in the study.

\section{Results}

4.1. Participants. The participants consisted of 111 teachers from the health care field. The majority of the teachers were women $(92 \%, n=102)$ and senior lecturers $(62 \%, n=68)$. The average work experience of the teachers was 11 years (ranging from 0.5 to 25 years). More than half of the teachers worked in the nursing programme $(58 \%, n=64)$. Twentytwo percent of the teachers $(n=24)$ had prior experience working for a company. Twelve percent $(n=13)$ of the teachers had worked as entrepreneurs. Most teachers (74\%, $n=82$ ) had some relatives working as entrepreneurs. In general, it was a spouse $(25 \%, n=33)$ or parent $(20 \% n=26)$ who worked as an entrepreneur (Table 1).

Approximately $23 \%$ of teachers $(n=25)$ reported that either they are teaching a course about entrepreneurship at present or they have taught a course on it previously (Table 1$)$. More than half $(n=16)$ of those teachers have taught about entrepreneurship as part of their own degree programme. The teachers who had worked in a company $(P<0.05)$ or worked as entrepreneurs $(P<0.05)$ teach about entrepreneurship more often than the others. Also, teachers who have participated in enterprise education tend to teach about entrepreneurship more often than the others $(P<0.05)$.

Approximately $33 \%$ of the teachers $(n=37)$ reported taking entrepreneurship into consideration fairly often or often when teaching other courses. The teachers with prior experience as entrepreneurs take it into consideration more often than the other teachers $(P<0.05)$. Also, those teachers who had previously received entrepreneurship education more actively exploit the possibilities of entrepreneurship in 
TABLE 1: Demographic characteristics of the teachers $(n=111)$.

\begin{tabular}{|c|c|c|}
\hline Demographics & $n$ & $\%$ \\
\hline \multicolumn{3}{|l|}{ Gender } \\
\hline Female & 102 & 92 \\
\hline Male & 9 & 8 \\
\hline \multicolumn{3}{|l|}{ Title } \\
\hline Principal lecturer & 20 & 18 \\
\hline Senior lecturer & 68 & 62 \\
\hline Lecturer & 19 & 17 \\
\hline Other & 3 & 3 \\
\hline \multicolumn{3}{|l|}{ Degree programme } \\
\hline Nursing & 64 & 58 \\
\hline Occupational therapy & 3 & 3 \\
\hline Physiotherapy & 8 & 7 \\
\hline Radiography care and radiotherapy & 7 & 6 \\
\hline Emergency care & 3 & 3 \\
\hline Biomedical laboratory science & 6 & 6 \\
\hline Public health service for the mouth & 6 & 6 \\
\hline Optometry & 1 & 1 \\
\hline Continuing education programmes & 12 & 11 \\
\hline \multicolumn{3}{|l|}{$\begin{array}{l}\text { Experienced in teaching about } \\
\text { entrepreneurship }\end{array}$} \\
\hline Yes & 25 & 23 \\
\hline No & 86 & 77 \\
\hline \multicolumn{3}{|l|}{ Experience with entrepreneurship } \\
\hline Worked in a company & 24 & 22 \\
\hline Worked as an entrepreneur & 13 & 12 \\
\hline \multicolumn{3}{|l|}{$\begin{array}{l}\text { Has a relative who has worked as an } \\
\text { entrepreneur }\end{array}$} \\
\hline Non & 28 & 25 \\
\hline Spouse & 28 & 25 \\
\hline Children & 6 & 6 \\
\hline Parents & 22 & 20 \\
\hline Sibling & 11 & 10 \\
\hline Other & 15 & 14 \\
\hline
\end{tabular}

their other courses $(P<0.05)$. Fourteen percent of the teachers have never taken entrepreneurship into consideration in their teaching (Table 2).

\subsection{Objectives and Content of Entrepreneurship Educa-} tion. The main objectives of entrepreneurship education were to start up or run a company, acquire knowledge about entrepreneurship, and teach students to become more entrepreneurial in their outlook. Most often the objective was for the students to learn about starting up or running a company. The central contents of the course pertained to starting up or running a company (developing a business idea or a business plan), entrepreneurship in general, and marketing. The courses also included information about, for example, production, work quality, leadership, and customer orientation (Table 3 ).
4.3. Teaching Methods for Entrepreneurship Education. When teaching about entrepreneurship, the most popular teaching method was company visits and case method. Other popular teaching methods were lecturing and project work. The teaching methods that teachers used the least were book examinations and essays. They did not use simulations at all (Table 4).

\subsection{Cooperation with Entrepreneurs. About half of the health} care teachers reported cooperating with entrepreneurs or companies fairly often or often. Those teachers who had previously worked as entrepreneurs $(P<0.05)$ or had participated in entrepreneurship education $(P<0.05)$ cooperate more with companies. Eleven percent of the teachers had never cooperated with entrepreneurs or companies (Table 2). The teachers listed different forms of cooperation with companies or entrepreneurs (Table 5). The most important forms of cooperation included the students' traineeships in the companies, cooperation in education, project cooperation, the thesis, and company visits. Some of the teachers reported cooperating in several ways.

\section{Discussion}

The requirements of education policy on EU press to respond to changing society. One of the requirements is the development of the entrepreneurial activities in health care education and these skills can be acquired through professional courses or by training. To teach entrepreneurship in health care education means that teachers should develop their knowledge about entrepreneurship and how to teach it.

Based on our study, less than a quarter of the teachers who participated in this study have been involved in teaching about entrepreneurship. Entrepreneurship teaching activities are positively associated with teachers' prior experience with entrepreneurship; this supports the findings of Hytti and O'Gorman [22]. A teacher in the health care field must be knowledgeable about and competent enough in matters related to entrepreneurship in health care to be able to support students in working towards becoming entrepreneurs. Therefore, health care teachers need to become more aware of the possibilities for entrepreneurship and they need to become more competent in teaching about entrepreneurship in health care so that they would be motivated and able to support entrepreneurial behaviour among their students [4]. Entrepreneurship is not deeply embedded in different courses; rather, it is for the most part limited to entrepreneurship programmes or courses. However, the health care teachers who participated in this study seem to be fairly well connected to the business world and to entrepreneurs. They have managed to expose their students to real business and working life through, for example, company visits, teaching cooperation, and practical training. Therefore, it is interesting to note that the teachers do not seem to exploit the opportunities for entrepreneurship education more widely in their different courses.

A majority of the content of the entrepreneurship courses identified in this study focused on starting up and running 
TABLE 2: The level of entrepreneurship consideration in teaching and the cooperation with entrepreneurs (teachers, $n=111$ ).

\begin{tabular}{|c|c|c|c|c|c|c|}
\hline & Never & Seldom & Fairly often & Often & \multirow[t]{2}{*}{ Mean } & \multirow[t]{2}{*}{ SD } \\
\hline & $\%(n)$ & $\%(n)$ & $\%(n)$ & $\%(n)$ & & \\
\hline $\begin{array}{l}\text { Teachers consideration } \\
\text { entrepreneurship in other courses } \\
\text { compared to special entrepreneur } \\
\text { courses }\end{array}$ & $14(16)$ & $53(58)$ & $23(26)$ & $10(11)$ & 2.3 & 0.84 \\
\hline $\begin{array}{l}\text { Teachers cooperation with companies } \\
\text { or entrepreneurs }\end{array}$ & $11(12)$ & $38(42)$ & $32(36)$ & $19(21)$ & 2.6 & 0.92 \\
\hline
\end{tabular}

TABLE 3: Content and objectives of entrepreneurship education $(n=$ how many times the content has been mentioned).

\begin{tabular}{|c|c|c|}
\hline $\begin{array}{l}\text { Content of } \\
\text { entrepreneurship } \\
\text { education }\end{array}$ & $\begin{array}{c}\text { mentions, } \\
n\end{array}$ & $\begin{array}{l}\text { Objective of } \\
\text { entrepreneurship } \\
\text { education }\end{array}$ \\
\hline $\begin{array}{l}\text { Establishment of the } \\
\text { company } \\
\text { (business idea and plan) }\end{array}$ & 13 & $\begin{array}{l}\text { To start up or run the } \\
\text { company }\end{array}$ \\
\hline $\begin{array}{l}\text { Entrepreneurship in } \\
\text { general }\end{array}$ & 9 & About entrepreneurship \\
\hline Marketing & 8 & $\begin{array}{l}\text { To start up or run the } \\
\text { company }\end{array}$ \\
\hline $\begin{array}{l}\text { How to become } \\
\text { entrepreneur }\end{array}$ & 6 & $\begin{array}{l}\text { To become } \\
\text { entrepreneurial }\end{array}$ \\
\hline Production & 6 & $\begin{array}{l}\text { To start up or run the } \\
\text { company }\end{array}$ \\
\hline Quality & 4 & $\begin{array}{l}\text { To start up or run the } \\
\text { company }\end{array}$ \\
\hline Leadership & 3 & $\begin{array}{l}\text { To start up or run the } \\
\text { company }\end{array}$ \\
\hline Legislation & 3 & $\begin{array}{l}\text { To start up or run the } \\
\text { company }\end{array}$ \\
\hline Customer orientation & 2 & $\begin{array}{l}\text { To start up or run the } \\
\text { company }\end{array}$ \\
\hline Financial management & 2 & $\begin{array}{l}\text { To start up or run the } \\
\text { company }\end{array}$ \\
\hline Networking & 2 & $\begin{array}{l}\text { To start up or run the } \\
\text { company }\end{array}$ \\
\hline $\begin{array}{l}\text { Ethics of the } \\
\text { entrepreneurship }\end{array}$ & 1 & About entrepreneurship \\
\hline Total & 59 & \\
\hline
\end{tabular}

a company. These teachers, thus, seem to be willing to support their students in learning to act as entrepreneurs and/or businesspersons in their future careers. This might be because these teachers have acted as entrepreneurs and the way how they think about organizing health care might be somewhat different than those teachers who have not been entrepreneurs.

The teachers who participated in this study do not seem to exploit often enough the objective of learning to become entrepreneurial, rather than just an entrepreneur. However, intrapreneurship and corporate entrepreneurship, that is, entrepreneurship within an existing organization $[35,36]$, might be most useful in the health care sector because nurses
TABLE 4: Teaching methods.

\begin{tabular}{lc}
\hline Methods & $\%$ \\
\hline Company visits and cases & 23 \\
Lectures & 15 \\
Project works & 11 \\
E-learning & 8 \\
Problem based learning & 8 \\
Practice in the company & 8 \\
Students' own business & 8 \\
Activities in study visits & 5 \\
Assignment from the companies & 5 \\
Thesis & 3 \\
Textbook examinations & 2 \\
Essays & 2 \\
Simulations & 0 \\
Other & 2 \\
\hline Total & 100 \\
\hline
\end{tabular}

TABLE 5: The cooperation forms between health care teachers and entrepreneurs.

\begin{tabular}{lc}
\hline Forms of cooperation & $n$ \\
\hline Students practice in the companies & 26 \\
Projects & 25 \\
Education (lectures to the company and by the & 24 \\
company) & 11 \\
Thesis & 9 \\
Company visits & 6 \\
Networking & 4 \\
Planning of further education & 6 \\
Others & 106 \\
\hline Total &
\end{tabular}

and other health care workers need to possess entrepreneurial skills in order to be able to cope with uncertainty and also changes in public sector organizations or political influences [5]. The reason can be that for health care teachers this kind of action mentioned in this study "intrapreneurship" was self-evident, but the word was unfamiliar. Intrapreneurship would be "accessible" for a greater number of students who might otherwise only consider entrepreneurship a remote option for their future careers. In addition, this might not pose too many challenges for the teacher either, since it makes 
it easier for the teachers to explore and teach about different entrepreneurial avenues.

Pedagogy is also an important part of entrepreneurship education. It makes a difference how entrepreneurship is being presented to the students [32]. The teachers in this study had used a variety of methods when teaching about entrepreneurship. Surprisingly teachers did not use simulations in their teaching. It may be due to the fact that teaching entrepreneurship is quite new in Finland and we do not have yet simulation labs for entrepreneurship education. More importantly, the teachers actively exposed their students to the business world. Traditional lecturing was also widely used by teachers. Previous studies suggest that it is not easy to say that one particular method would be better than other methods [32]. On the other hand, traditional teaching methods are unlikely to adequately inform students about entrepreneurial behaviour and more importantly to give them a possibility to "taste" entrepreneurial action in practice [37]. Therefore, there needs to be a balance between different methods and they need to reflect the target audience and the objectives of the entrepreneurship programme. Health care teachers need the continuing education concerning the teaching methods which are usable in teaching entrepreneurship. Moreover, it would be useful to arrange the continuing education to the teacher about how to teach intrapreneurial skills.

The teachers also reported using methods that are based on working life, such as company visits or expert lectures from companies. In this study, the teachers reported that they cooperated quite often with external entrepreneurs or companies. The majority of teachers cooperate with entrepreneurs and companies at least every now and then even though they do not teach about entrepreneurship the cooperation can be quite multifaceted. The entrepreneurs can support the learning process of the students and also the teacher's development as an educator [22]. Even though the teachers cooperate with entrepreneurs, they do not take entrepreneurship into consideration very often in their other teaching activites. The skills and competence necessary for entrepreneurship should be integrated with other teaching activities [22]. This requires making the objectives of enterprise education more general throughout the curriculum used in the health care field. Even more important it would be to integrate teaching intrapreneurial skills with other teaching activities and subjects.

5.1. Validity and Reliability of the Study. The questionnaire was piloted in order to strengthen its reliability. After the pretesting, some choices of phrasing were modified and made more understandable. The external validity [38] was improved via a renewal inquiry, which was carried out approximately two weeks after the first inquiry. The renewal inquiry improved the response rate, but even then, the final response rate was only $23 \%$. This weakens the generalizability of the study. However, a low response rate is typical when collecting material via e-mail [39]. The low response rate can possibly be an indication of the teachers' general lack of interest or a negative attitude towards entrepreneurship. Despite these limitations, the subject is very important for society and the subject has been little studied throughout Europe. Geographically, the teachers were representative of the distribution of the health care teacher population throughout Finland; also, according to the background factors the teachers represented the national average for health care teachers [40].

\section{Conclusion}

Due to the changes in working life, entrepreneurial skills are necessary in the health care field, irrespective of the sector. For this reason, education programmes in health care should pay more attention to entrepreneurship in the curriculum. Only a minority of the teachers in the field of health care teach about entrepreneurship at the moment, even though many teachers cooperate with entrepreneurs and companies. Teachers in the health care field would become more acquainted with entrepreneurship education if they received more training in how to teach it. In particular, the teaching methods need to be emphasized in entrepreneurship education. If this were the case, more teachers would probably use traditional teaching methods less often and begin to adopt more experiential learning methods. Very little research has been done on entrepreneurship in the health care sector and particularly on enterprise education in nursing education. Future studies should clarify what kind of teaching methods is suitable for enterprise education in the health care field.

\section{Conflict of Interests}

The authors declare that there is no conflict of interests regarding the publication of this paper.

\section{References}

[1] ICN, Guidelines on the Nurse Entre/Intrapreneur Providing Nursing Service, ICN, Geneva, Switzerland, 2004.

[2] M. Kingma, "Marketing and nursing in a competitive environment," International Nursing Review, vol. 45, no. 2, pp. 45-50, 1998.

[3] A. Wilson, A. Averis, and K. Walsh, "The scope of private practice nursing in an Australian sample," Public Health Nursing, vol. 21, no. 5, pp. 488-494, 2004.

[4] J. Boore and S. Porter, "Education for entrepreneurship in nursing," Nurse Education Today, vol. 31, no. 2, pp. 184-191, 2011.

[5] Department of Health, Leading the Way through Social Enterprise-The Social Enterprise Pathfinder Evaluation, Stationery Office, London, UK, 2010.

[6] V. Drennan, K. Davis, C. Goodman et al., "Entrepreneurial nurses and midwives in the United Kingdom: an integrative review," Journal of Advanced Nursing, vol. 60, no. 5, pp. 459-469, 2007.

[7] B. Elango, G. L. Hunter, and M. Winchell, "Barriers to nurse entrepreneurship: a study of the process model of entrepreneurship," Journal of the American Academy of Nurse Practitioners, vol. 19, no. 4, pp. 198-204, 2007. 
[8] M. R. Shirey, "An evidence-based understanding of entrepreneurship in nursing," Clinical Nurse Specialist, vol. 21, no. 5, pp. 234-240, 2007.

[9] M. Sankelo and L. Åkerblad, "Nurse entrepreneurs' attitudes to management, their adoption of the managers's role and managerial assertiveness," Journal of Nursing Management, vol. 16, no. 7, pp. 229-236, 2008.

[10] J. Österberg-Högstedt, Yrittäjänä ammatissaan sosiaali-ja terveysalalla-yrittäjyyden muotoutuminen kuntatoimijoiden ja yrittäjien näkökulmasta [Academic Dissertation], Turku School of Economics, Turku, Finland, 2009 (Finnish).

[11] P. Roberts, B. Bridgwood, and R. Jester, "Development of entrepreneurial activity in nurse education," Nursing Standard, vol. 23, no. 28, pp. 35-41, 2009.

[12] Ministry of Education, Guidelines for Entrepreneurship Education, Publications of the Ministry of Education 9, Ministry of Education, Department of Education and Science, 2009.

[13] European Commission, "Entrepreneurship in higher education, especially with in non-business studies," Final Report of the Expert Group, European Commission, Enterprise and Industry Directorate-general, Brussels, Belgium, 2008, http:// ec.europa.eu/enterprise/policies/sme/files/support_measures/ training_education/entr_highed_en.pdf.

[14] D. Ucbasaran, P. Westhead, and M. Wright, "The focus of entrepreneurial research," Contextual and Process Issues, Entrepreneurship Theory and Practice, vol. 25, no. 4, pp. 57-80, 2001.

[15] European Commission, Implementing the Community Lisbon Programme: Fostering Entrepreneneurial Mindsets Through Education and Learning, COM 33 Final, Commission of the European Communities, Brussels, Belgium, 2006.

[16] S. Shane and S. Venkataraman, "The promise of entrepreneurship as a field of research," Academy of Management Review, vol. 25, no. 1, pp. 217-226, 2000.

[17] C. L. Shook, R. L. Priem, and J. E. McGee, "Venture creation and the enterprising individual: a review and synthesis," Journal of Management, vol. 29, no. 3, pp. 379-399, 2003.

[18] H. Landström, “The roots of entrepreneurship research," in Proceedings of the 11th RENT Conference, Lyon, France, November 1998.

[19] A. Gibb, "In pursuit of a new "enterprise" and "entrepreneurship" paradigm for learning: creative destruction, new values, new ways of doing things and new combinations of knowledge," International Journal of Management Reviews, vol. 4, no. 3, pp. 233-269, 2002.

[20] J. Heinonen, "An entrepreneurial-directed approach to teaching corporate entrepreneurship at university level," Education and Training, vol. 49, no. 4, pp. 310-324, 2007.

[21] R. D. Ireland, J. G. Covin, and D. F. Kuratko, "Conceptualizing corporate entrepreneurship strategy," Entrepreneurship: Theory and Practice, vol. 33, no. 1, pp. 19-46, 2009.

[22] U. Hytti and C. O'Gorman, "What is "enterprise education"? An analysis of the objectives and methods of enterprise education programmes in four European countries," Education + Training, vol. 46, no. 1, pp. 11-23, 2004.

[23] P. Blenker, P. Dreisler, and J. Kjeldsen, "Entrepreneurship education-the new challenge facing the universities. A framework or understanding and development of entrepreneurial university communities," Working Paper 2006:2, Department of Management, 2006.
[24] M. Klofsten, "Training entrepreneurship at universities: a Swedish case," Journal of European Industrial Training, vol. 24, no. 6, pp. 337-344, 2000.

[25] European Commission, Final Report of the Expert Group "Best Procedure" Project on Education and Training for Entrepreneurship, Commission of the European Communities, Brussels, Belgium, 2002.

[26] U. Hytti, State-of-Art of Enterprise Education in Europe. Results from the ENTREDU Project, Turku School of Economics, Tampere, Finland, 2002.

[27] A. A. Gibb, "The future of entrepreneurship educationdetermining the bases for coherent policy and practice?" in The Dynamics of Learning Entrepreneurship in a Cross-Cultural University Context, P. Kyrö and C. Carrier, Eds., Entrepreneurship Education Series 2/2005, pp. 44-67, University of Tampere, Research Centre for Vocational and Professional Education, Hämeenlinna, Finland, 2005.

[28] J. Heinonen and U. Hytti, "Back to basics: the role of teaching in developing the entrepreneurial university," International Journal of Entrepreneurship and Innovation, vol. 11, no. 4, pp. 309-318, 2010.

[29] I. Berry, A. Kumar, and J. P. Scott, "Is innovation being addressed in entrepreneurship undergraduate programs? An exploratory study," Education Research International, vol. 2014, Article ID 839505, 7 pages, 2014.

[30] S. L. Jack and A. R. Anderson, "Entrepreneurship education within the enterprise culture. Producing reflective practitioners," International Journal of Entrepreneurship Behaviour \& Research, vol. 5, no. 3, pp. 110-125, 1999.

[31] D. Rae, "Entrepreneurial learning: a narrative-based conceptual model," in Proceedings of the Institute for Small Business Affairs 27th National Conference, Newcastle Gateshead, UK, November 2004.

[32] J. Heinonen and E. Akola, "Entrepreneurship training and entrepreneurial learning-ENTLEARN," in Best Practice Guide for Educators and Policy-Makers, TSE Entre, Tampere, Finland, 2007.

[33] J. Heinonen and E. Akola, Entrepreneurship Training and Entrepreneurial Learning in Europe. Results from the ENTLEARN project, TSE Entre, Tampere, Finland, 2007.

[34] P. Kyrö and C. Carrier, "Entrepreneurial learning in universities: bridges across borders," in The Dynamics of Learning Entrepreneurship in a Cross-Cultural University Context, P. Kyrö and C. Carrier, Eds., Entrepreneurship Education Series 2/2005, pp. 14-43, University of Tampere, Research Centre for Vocational and Professional Education, Hämeenlinna, Finland, 2005.

[35] B. Antoncic and R. D. Hisrich, "Intrapreneurship: construct refinement and cross-cultural validation," Journal of Business Venturing, vol. 16, no. 5, pp. 495-527, 2001.

[36] B. Antoncic and R. D. Hisrich, "Clarifying the intrapreneurship concept," Journal of Small Business and Enterprise Development, vol. 10, no. 1, pp. 7-24, 2003.

[37] J. Heinonen and S. A. Poikkijoki, "An entrepreneurial-directed approach to entrepreneurship education: mission impossible?" Journal of Management Development, vol. 25, no. 1, pp. 80-94, 2006.

[38] N. Burns and S. K. Grove, The Practice of Nursing Research: Conduct, Critique and Utilization, Elsevier Saunders, Philadelphia, $\mathrm{Pa}$, USA, 5th edition, 2005. 
[39] M. E. Duffy, "Methodological issues in Web-based research," Journal of Nursing Scholarship, vol. 34, no. 1, pp. 83-88, 2002.

[40] Ministry of Social Affairs and Health, "Maintenance and development of Health care teacherss ' professional knowledge and skills," Reports of the Ministry of Social affairs and Health, Publication 2007:29, 2007, Original in Finnish, abstract in English. 

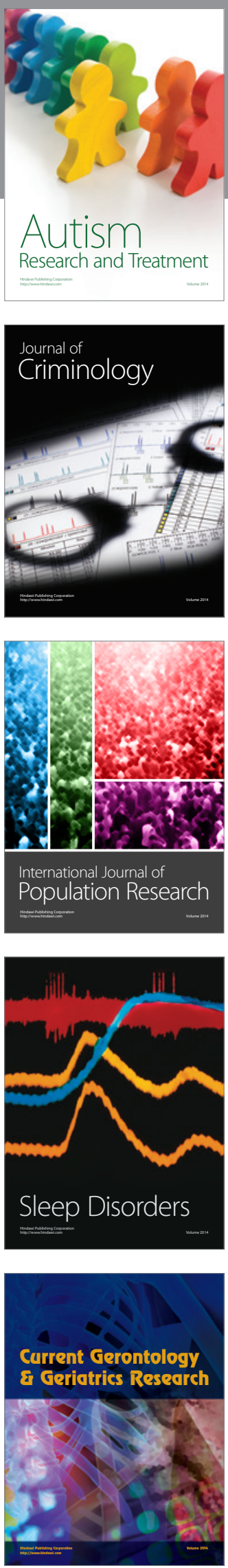
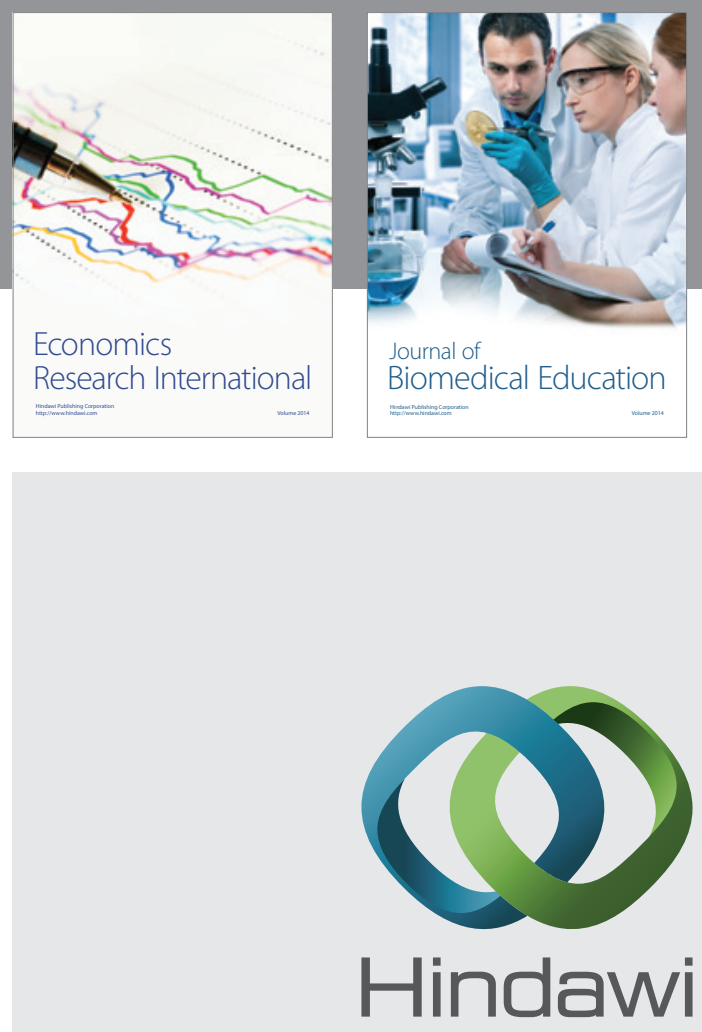

Submit your manuscripts at

http://www.hindawi.com
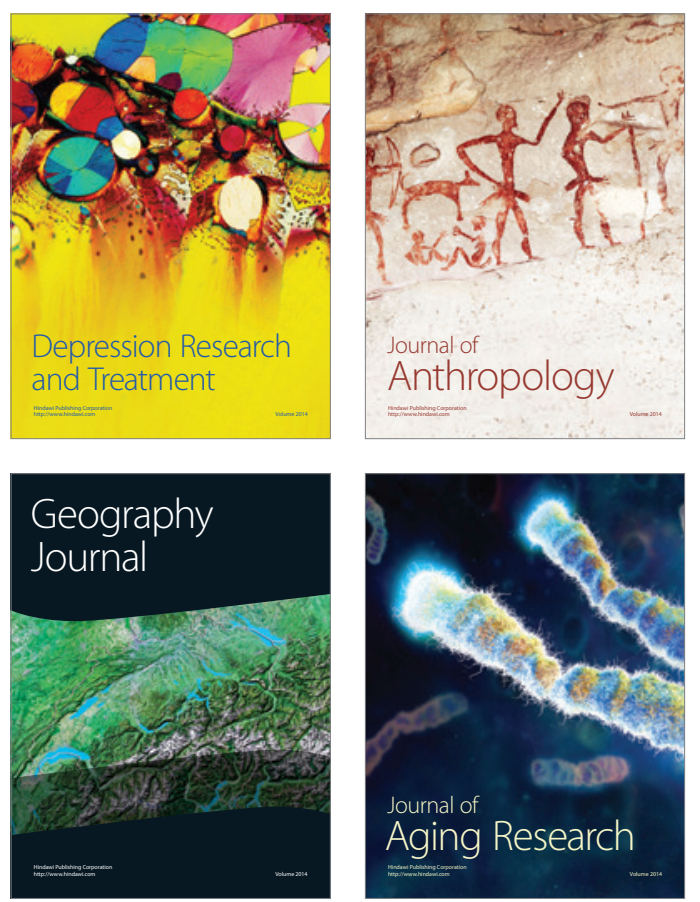
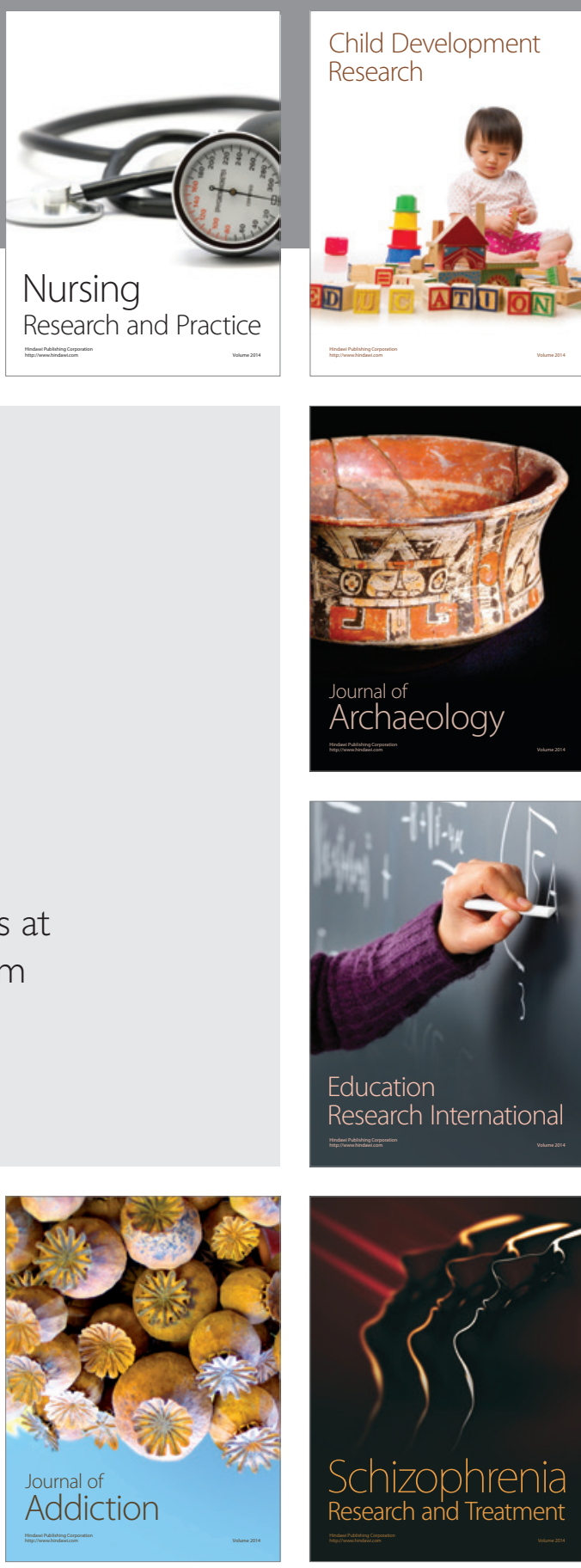

(D)
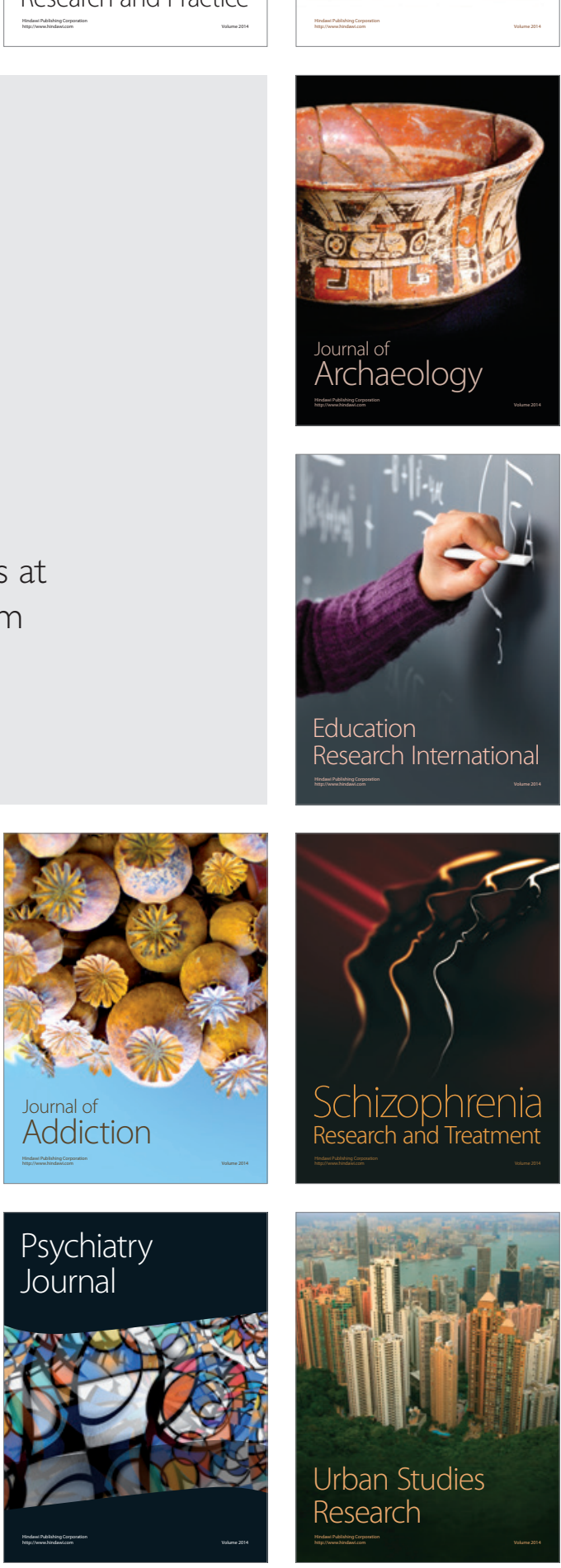